Association for Information Systems

AIS Electronic Library (AISeL)

ICEB 2009 Proceedings

International Conference on Electronic Business

(ICEB)

Winter 12-4-2009

\title{
How Does a Retailer's Service Plan Affect a Manufacturer's Warranty?
}

Bo Jiang

Department of Decision Sciences and Managerial Economics The Chinese University of Hong Kong, Hong Kong, jiangbo_dse@baf.msmail.cuhk.edu.hk

Xubing Zhang

The Hong Kong Polytechnic University, msxubing@inet.polyu.edu.hk

Follow this and additional works at: https://aisel.aisnet.org/iceb2009

\section{Recommended Citation}

Jiang, Bo and Zhang, Xubing, "How Does a Retailer's Service Plan Affect a Manufacturer's Warranty?" (2009). ICEB 2009 Proceedings. 42.

https://aisel.aisnet.org/iceb2009/42

This material is brought to you by the International Conference on Electronic Business (ICEB) at AIS Electronic Library (AISeL). It has been accepted for inclusion in ICEB 2009 Proceedings by an authorized administrator of AIS Electronic Library (AISeL). For more information, please contact elibrary@aisnet.org. 


\title{
HOW DOES A RETAILER'S SERVICE PLAN AFFECT A MANUFACTURER'S WARRANTY?
}

\author{
Jiang, Bo ${ }^{1}$, Zhang, Xubing ${ }^{2}$ \\ ${ }^{1}$ Department of Decision Sciences and Managerial Economics \\ The Chinese University of Hong Kong, Hong Kong \\ ${ }^{2}$ The Hong Kong Polytechnic University \\ ${ }^{1}$ jiangbo_dse@baf.msmail.cuhk.edu.hk; ${ }^{2}$ msxubing@inet.polyu.edu.hk
}

Keywords: Service Plans, Warranty; Signaling, Distribution Channels, Game Theory.

\section{A Summary}

Service plans are a type of warranty contract under which retailers promise to repair or replace products for consumers. Separate from manufacturers' warranty policies, which typically come bundled with the products, and also known as service contracts, protection plans, or retailer extended warranties, retailers' service plans are optional and usually offer broader and more prolonged coverage than those offered by manufacturers' base warranties. Today, these plans are available for almost all durable goods in retail stores, and so pervasive that it is rare to find a major retailer in the U.S. that does not provide them. In fact, it has become the norm that, when purchasing a product, consumers are faced with warranties offered by multiple parties, typically the manufacturer base warranty that is bundled with the product and an optional retail service plan.

It is well documented that manufacturers use warranties to protect consumers against product failure and to signal product quality. In this paper, we argue that these roles of the manufacturer's warranty can be affected by the offering of retail service plans. From the consumer's point of view, the retailer's service plan complements and can even substitute for the manufacturer's base warranty. Given that the retailer has already offered a more extended warranty, it seems obvious that the manufacturer should offer a minimal warranty so as to avoid free-riding on the part of the retailer. So why does manufacturer still offer a base warranty? More generally, what motivates manufacturers to offer a base warranty when service plans are available to consumers? What are the strategic interactions between the retail service plan and the manufacturer base warranty? How do these service plans affect the role of manufacturers' warranties and channel performance?

Regardless of the prevalence of service plans in the retail sector, studies on these plans and their interactions with manufacturers' warranties are scarce. The present research strives to contribute to a better understanding of the role of the retail service plan in distribution channels in which the manufacturer also offers a (base) warranty. Our investigation starts with a context in which consumers are able to assess product quality--in this research, high quality refers to a high degree of reliability in product performance (or a low risk of product failure). It then addresses the more interesting scenario of consumers being unable to assess that quality. It is well accepted that when quality is unobservable to consumers, a high quality manufacturer has the incentive to use a warranty to signal quality (Spence 1977). Our research therefore specifically investigates the role of a retailer's service plan in the manufacturer's signaling strategy. To concentrate on the signaling issues involved in warranty strategy, we abstract from the consumer moral hazard problem by assuming that consumer action does not affect the quality or reliability of products. Consequently, the results of our analysis are most applicable to products that require little consumer maintenance and present little opportunity for consumer moral hazard.

We consider a market in which a manufacturer markets a product through a retailer to a group of consumers. The product is subject to a certain probability of failure. The consumers are heterogeneous in their willingness to pay to avoid the incidence of product failure. In a model with complete information, we assume that the quality of the product is known by all parties in the market. The manufacturer determines whether to bundle the product with a base warranty, and sets a wholesale price accordingly. Based on the manufacturer's decisions, the retailer then sets a retail price for the product and a price for an optional service plan, if it is offered. Consumers then determine whether to purchase the product and the service plan. In such a context, offering an optional service plan can help the retailer to promote product demand, and segment 
and better serve heterogeneous consumers. We show that when the retailer offers a service plan, the manufacturer offers its warranty only if it is more cost efficient than the retailer in providing a warranty.

We then develop models with incomplete information where the probabilistic product failure rate, either high or low, is determined by nature and known only to the manufacturer and the retailer, not known to the consumers. In such cases, a high quality manufacturer will have the incentive to signal its quality. Intuition suggests that in the presence of a more extended retail service plan, a high quality manufacturer should reduce its warranty coverage to avoid free-riding on the part of the retailer (Lutz and Padmanabhan 1995). In addition, because consumers who are very concerned about product quality can opt for a service plan to obtain peace of mind, it appears that the presence of such a service plan should also reduce consumers' need for a signal from the manufacturer, thus reducing that manufacturer's incentive to signal. Indeed, we find that the presence of a service plan can nullify the effects of a manufacturer's offering of a (longer or greater) base warranty as a signaling strategy, i.e., the availability of service plans can diminish the positive relationship between warranty and quality, as suggested by the signaling rationale of warranty. However, we also find that, in the presence of a service plan, a high quality manufacturer may have greater incentive to signal and offer greater warranty coverage in the signaling equilibrium. It is even possible that the greater the coverage of the service plan, the greater the incentive the manufacturer has to signal and the greater base warranty coverage it offers. These unexpected results highlight two opposing effects of a service plan on a manufacturer's incentive to signal quality by offering a warranty. Because, from the consumer's point of view, a service plan can substitute for the manufacturer's warranty, the availability of such a plan makes the presence of a manufacturer warranty less attractive. This mitigates the manufacturer's motivation to use a warranty to signal quality. At the same time, however, because a service plan can promote demand for a product, it can also enhance the manufacturer's motivation for such signaling. Therefore, when consumers are unable to access product quality, the impact of a service plan on the manufacturer's warranty strategy depends on these two opposing effects.

The presence of a service plan also affects the profits of both the manufacturer and the retailer. We find that whether or not consumers are able to assess product quality, offering a service plan always increases profits for the retailer, but not necessarily for the manufacturer. The retailer cannot be rendered worse off by the acquisition of an additional marketing instrument, whereas the manufacturer will be better off only if the retailer's cost for providing the service plan is low enough.

\section{Literature Review}

There is a rich body of literature on product warranties. The insurance role of warranties was understood fairly early on and documented by Heal (1977). In this view, warranties provide insurance against product failure to risk-averse consumers. Because consumers have heterogeneous preferences for warranty coverage, the literature also shows that a seller can use a menu of warranty coverage to screen (i.e., to segment) consumers (Mussa and Rosen 1978). For instance, an optimal policy may consist of two warranty options, with a base warranty being offered to less risk-averse consumers and an extended warranty to more risk-averse consumers. When consumers' actions are unobservable but affect product liability, it has been shown that the consumer moral hazard problem can affect a firm's warranty strategy for screening (Padmanabhan and Rao 1993).

Spence (1977) initiated a new branch of research on the signaling role of warranty. In markets in which product quality is not readily observable to consumers, a high quality manufacturer can use a better or longer warranty to signal its quality if it is too costly for a low quality manufacturer to offer the same coverage. Soberman (2003) considers a situation in which a seller uses a warranty both to screen and to signal, and shows that signaling can limit the seller's ability to screen because, to signal, it generally lengthens the base warranty and shortens the optional extended warranty. Lutz (1989) examines the use of prices and warranties as signals of product quality under consumer moral hazard and shows that, surprisingly, quality can be signaled with a low-coverage warranty. Although firms should take the consumer moral hazard problem into account when making warranty policy for certain products, we focus on other products that present little opportunity for the problem to highlight the signaling role played by the manufacturer's warranty.

Provided that high quality products are less expensive to guarantee than low-quality products, it seems intuitively reasonable that an observable warranty could serve as a signal of unobservable product quality. It has been verified that a warranty can influence consumers' risk perceptions (Bearden and Shimp 1982). However, although some researchers have evidenced better and longer warranties as signals of high product quality (Wiener 
1985, Kelley 1988, Boulding and Kirmani 1993), others have found lower quality products to offer longer warranties (Bryant and Gerner 1978, Gerner and Bryant 1981). A number of models have been proposed to address this inconsistency. Gal-Or (1989) showed that oligopolistic competition in a product market could affect firms' incentives, such that higher quality would be signalled by a lower warranty coverage. Balachander (2001) shows that a less reliable product may carry a longer warranty in a product market in which a new entrant competes with an established product. More researchers have argued that in the presence of consumer moral hazard, high-quality firms may optimally choose to offer less warranty coverage than low-quality ones because a strong warranty results in a low degree of maintenance effort on the part of consumers (Cooper and Ross 1985, Lutz 1989, Dybvig and Lutz 1993). Our results contribute to this stream of research by offering an alternative explanation for the weak relationship between quality and warranty: the presence of retailer service plans can diminish the correlation between them.

The role of warranty has also been studied in the context of the supply chain, with a focus on channel coordination. Desai and Padmanabhan (2004) show that a manufacturer can use its warranty to coordinate a bilateral-monopoly distribution channel. In their model, the manufacturer warranty can be offered through three channel arrangements, direct (i.e., selling though the manufacturer itself), indirect (i.e., selling through a retailer) and dual distribution (i.e., selling through a combination of the aforementioned two). They find that the ability of a manufacturer to market a complementary good (i.e., a warranty) that helps to combat the price coordination problem in a channel alleviates its need to consider forward integration as a means of combating double marginalization. In an unpublished paper, Li et al. (2008) examine the role of warranty in a bilateral-monopoly distribution framework, but they assume that the warranty is offered by either the manufacturer or the retailer (but not by both). With reduced-form demand functions, they show that when the warranty is offered by the retailer, it has longer coverage and the system profit is greater.

In all of the aforementioned, the warranty option(s) is assumed to be offered by one firm only. To the best of our knowledge, only two studies are exceptional in this regard, those carried out by Lutz and Padmanabhan $(1995,1998)$.

In the context of consumer moral hazard, Lutz and Padmanabhan (1995) provide an explanation for the minimal manufacturer base warranties observed in certain markets. They show that the provision of an extended warranty by an independent insurer and the presence of consumer moral hazard create a negative cost externality on the manufacturer's warranty. To avoid the insurer free-riding on its own warranty, the manufacturer bundles its product with a minimal base warranty. Under conditions of producer moral hazard, these researchers (Lutz and Padmanabhan 1998) also focus on a manufacturer's ability to use a menu of warranties to segment consumers. They show that the availability of extended warranties from an independent insurer has an important effect on a menu of warranties to screen, and that the entry of the insurer can, surprisingly, increase the manufacturer's profits.

The present research is among the few theoretical studies to explicitly model the interactions between warranties offered by different firms. Moreover, it is the first study on warranty in a distribution channel context in which both the upand down-stream parties offer a warranty, and it is the first attempt to examine the interactions between warranties from a signaling perspective. We offer a number of insights that have not been addressed in the previous literature.

\section{Concluding Remarks}

Service plans are a type of optional warranty beyond the manufacturer's base warranty that retailers offer to consumers. Regardless of their prevalence and nontrivial implications in distribution channels, research on service plans is scarce. In this paper, we examine the impacts of a retailer's service plan on a manufacturer's base warranty policy and on channel performance. Analysis shows that when consumers can assess product quality, in the presence of a service plan, a manufacturer should not offer a base warranty unless it is more cost efficient than the retailer in providing that warranty. When consumers cannot assess product quality, a high quality manufacturer is motivated to use its own warranty to signal that quality. In such cases, we find that, in the presence of a service plan, the manufacturer's base warranty serves as a credible signal only when the manufacturer is less cost efficient. The service plan can render the manufacturer's signaling either more or less viable, and result in either greater or lesser warranty coverage in the signaling equilibrium. Whether or not consumers can assess product quality, offering a service plan always increases profits for the retailer and the channel as a whole, but not necessarily for the manufacturer.

\section{References}

[1] Balachander, S. 2001. Warranty signaling an d reputation. Management Sci. 47(9) 1282-1 289. 
[2] Bearden, W., T. Shimp. 1982. The use of extrinsic cues to facilitate product adoption. J. Marketing Res. 19(2) 229-239.

[3] Boulding, W., A. Kirmani. 1993. A consum er-side experimental examination of signalin g theory: do consumers perceive warranties as signals of quality? J. Consumer Res. 2 0(1) 111-123.

[4] Bryant, W. K., J. Gerner. 1978. The price of a warranty: The case for refrigerators. $J$. Consumer Affairs 12 30-47.

[5] Bryant, W. K., J. Gerner. 1982. The deman d for service contracts. J. Business 55(3) 3 45-366.

[6] Cooper, R., T. W. Ross. 1985. Product warr anties and double moral hazard. Rand J. E conom. 16(1) 103-113.

[7] Desai, P. S., V. Padmanabhan. 2004. Durab le good, extended warranty and channel co ordination. Rev. Marketing Sci. 2 1-23.

[8] Dybvig, P. H., N. A. Lutz. 1993. Warrantie s, durability and maintenance: two-sided mo ral hazard in a continuous-time model. Rev. Econom. Stud. 60(3) 575-97.

[9] Gal-Or, E. 1989. Warranties as a signal of quality. Canadian J. Econom. 22(1) 50-61.

[10] Gerner, J. L., W. K. Bryant. 1981. Applian ce warranties as a market signal? J. Consu mer Affairs. 15(1) 75-86.

[11] Heal, G. 1977. Guarantees and risk-sharing. Rev. Econom. Stud. 44(3) 549-560.

[12] Kelley, C. A. 1988. An investigation of co nsumer product warranties as market signals of product reliability. J. Academy Marketin g Sci. 16(2) 72-78.

[13] Li, K., D. Chhajed, S. Mallik. 2008. Desig $\mathrm{n}$ of extended warranties in supply chains.
Working Paper, University of Illinois, Urba na-Champaign.

[14] Lutz, N. A. 1989. Warranties as signals un der consumer moral hazard. Rand J. Econo m. 20(2) 239-255.

[15] Lutz, N. A., V. Padmanabhan. 1995. Why do we observe minimal warranties? Marketi ng Sci. 14(4) 417-441.

[16] Lutz, N. A., V. Padmanabhan. 1998. Warra nties, extended warranties, and product qual ity. Internat. J. Industrial Organization 16(4) 463-493.

[17] Maronick, J. T. 2007. Consumer perceptions of extended warranties. J. Retailing and $C$ onsumer Services 14 224--231.

[18] Moorthy, K. S., K. Srinivasan. 1995. Signal ing quality with a money-back guarantee: $\mathrm{T}$ he role of transaction costs. Marketing Sci. 14(4) 442-466.

[19] Mussa M., S. Rosen. 1978. Monopoly and product quality. J. Econom. Theory 18(2) 3 01-17.

[20] Nelson, P. 1974. Advertising as information. J. Political Econom. 81(4) 729-754.

[21] Padmanabhan, V., R. C. Rao. 1993. Warran ty policy and extended service contracts: $\mathrm{T}$ heory and an application to automobiles. $M$ arketing Sci. 12(3) 230-247.

[22] Soberman, D. A. 2003. Simultaneous signal ing and screening with warranties. J. Marke ting Res. 40(2) 176-192.

[23] Spence, A. M. 1977. Consumer mispercepti ons, product failure and producer liability. Rev. Econom. Stud. 44(3) 561-572.

[24] Wiener, J. L. 1985. Are warranties accurate signals of product reliability? J. Consumer Res. 12(2) 245-250. 